\title{
IS THE STABILITY \\ OF LEVERAGE RATIOS DETERMINED BY THE STABILITY \\ OF THE ECONOMY?
}

\section{Anastasiya Shamshur}
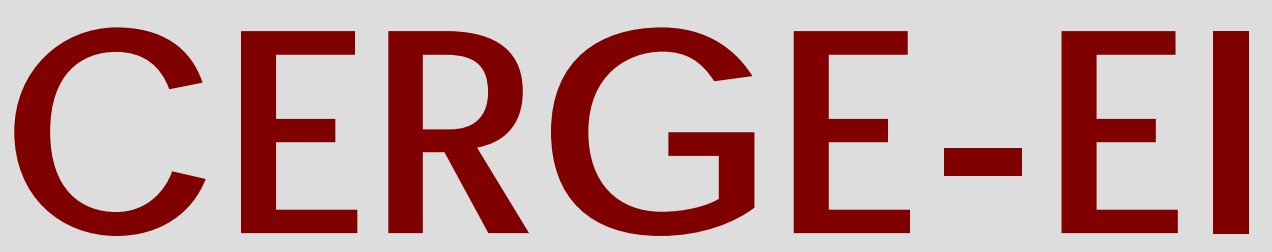

Charles University Centerfor Economic Research and Graduate Education Academy of Sciences of the Czech Republic Ec onomic s Institute 


\title{
Working Paper Series (ISSN 1211-3298)
}

\section{Is the Stability of Leverage Ratios Determined by the Stability of the Economy?}

Anastasiya Shamshur

\author{
CERGE-EI \\ Prague, September 2009
}

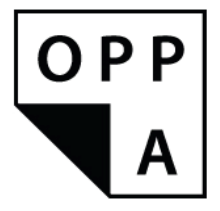

\begin{tabular}{l|l|} 
PRA & HA \\
PRA & GUE \\
PRA & GA \\
PRA & G \\
\hline
\end{tabular}

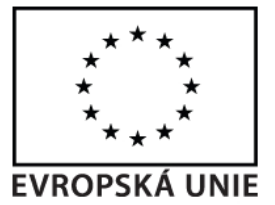

EVROPSKÝ SOCIÁLNÍ FOND

PRAHA \& EU: INVESTUJEME DO VAŠÍ BUDOUCNOSTI

Projekt je financován Evropským sociálním fondem, rozpočtem hl. města Prahy a státním rozpočtem 
ISBN 978-80-7343-195-2 (Univerzita Karlova. Centrum pro ekonomický výzkum a doktorské studium)

ISBN 978-80-7344-184-5 (Národohospodářský ústav AV ČR, v.v.i.) 


\title{
Is the Stability of Leverage Ratios Determined by the Stability of the Economy?*
}

\author{
Anastasiya Shamshur ${ }^{\dagger}$ \\ CERGE-EI ${ }^{\ddagger}$
}

September 2009

\begin{abstract}
The choice of capital structure by firms is a fundamental issue in financial literature. According to a recent finding, the capital structure of firms remains almost unchanged during their lives meaning that leverage ratios are significantly stable over time. The stability of leverage ratios is mainly generated by an unobserved firm-specific effect that is liable for the majority of variation in capital structure (Lemmon, Roberts, and Zender 2008). However, the study focuses on the US economy, which is relatively stable. I study how substantial changes in the economy affect the stability of firms' capital structure in transition countries. Specifically, I concentrate on Central and Eastern European economies that passed through transition from central planning to a market economy and privatization, the Russian financial crisis, and EU membership. In addition, I investigate whether the ownership structure of firms is responsible for the part of the unexplained variation in leverage.

Volba kapitálové struktury firmami je základním tématem finanční literatury. Podle současných poznatků se ukazuje, že kapitálová struktura firmy zůstává během jejího života nezměněna, což znamená, že poměr závazků a majetku je v čase poměrně stabilní. Jeho stabilita je způsobena především nepozorovaným pro firmu specifickým efektem, který je odpovědný za většinu variace v kapitálové struktuře (Lemmon, Roberts, and Zender 2008). Tato studie se ale zaměřuje na relativně stabilní ekonomiku Spojených Států. Já se naopak zaměřuji na transformující se ekonomiky a studuji změnu kapitálové struktury firem v těchto zemích. Zaměřuji se na ekonomiky Střední a Východní Evropy, které prošly transformací z centrálního plánování směrem k tržní ekonomice a privatizaci. Dále studuji efekt finanční krize v Rusku a členství v EU. Rovněž se zabývám tím, zda je vlastnická struktura firem zodpovědná za část nevysvětlené variace v poměru závazků a majetku.
\end{abstract}

Keywords: Capital Structure, Financing Decisions, Eastern Europe

JEL classification: G32, C23

${ }^{*}$ I would like to thank Jan Hanousek for helpful suggestions and comments. I also benefited from the comments by Ronald Masulis, Martijn Cremers, Andreas Ortmann and Junghun Cho. Financial support from GAUK grant (project No. 56909) and GAČR grant (402/09/1595) is gratefully acknowledged. While working on the paper, I also benefited from World bank fellowhip.

$\dagger$ Email: anastasiya. shamshur@cerge-ei.cz

${ }^{\ddagger}$ Center for Economic Research and Graduate Education--Economics Institute, a joint workplace of Charles University in Prague and the Academy of Sciences of the Czech Republic. Address: CERGE-EI, P.O. Box 882, Politických vězňů 7, Prague 1, 111 21, Czech Republic 


\section{Introduction}

Capital structure choice is an important decision for a firm. It is important not only from the returns maximization point of view, but also because this decision has a great impact on a firm's ability to successfully operate in a competitive environment. Current literature has suggested a number of factors that can explain about $30 \%$ of the total variation in capital structure. However, Lemmon, Roberts, and Zender (2008) notice that the capital structure of firms remains almost unchanged from their birth to death meaning that leverage ratios are significantly stable over time. The authors also stress that the stability of leverage ratios is not affected by the process of going public, but it is mainly generated by an unobserved firm-specific effect that is responsible for the majority of variation in capital structure.

As Lemmon, Roberts, and Zender (2008) focus on the US economy which is relatively stable over time, their finding raises the question whether this significant stability in leverage ratios is determined by the stability of the economy the firms operate in. The impact of substantial changes in the economy on capital structure stability has not been studied yet. In the US context, it could be investigated how the capital structure of firms changes in response to a crisis. For example, Lemmon, Roberts, and Zender (2008) use a sample that consists of all non-financial firm-year observations between 1963 and 2003. This time span embraces the US savings and loan crisis in the 1980s and the dot-com bubble. However, neither of these crises caused deep recession or depression of production and investment in the economy as a whole. The financial sector was stabilized and continued growing after funds infusion. So, both crises did not dramatically affect the stability of the US economy.

In this paper I focus on countries that experienced substantial changes in all economic spheres during transition. There are several events that could have a strong impact on firms' capital structures. These are transition from a central planning to market economy and privatization, the Russian financial crisis, and EU membership.

After the USSR collapsed (in 1991), the former USSR countries started the pro- 
cess of transition from a centrally planned system to a market-oriented economy or, in other words, started reconstruction of their whole economic systems. This process stimulated large-scale privatization with complete rebuilding of firms' capital structure in accordance with their needs and opportunities. All these transformations in the economy were accompanied by the evolution of national accounting systems and application of international standards. The total mess in accounting was aggravated by accounting dishonesty. In this situation large asymmetric information hinders getting outside sources of finance for firms even if their investment opportunities exceeded their internal funds. Even now debt remains the main source of financing in many transition countries due to underdeveloped capital markets and lack of equity capital. Firms were experiencing hard credit constraints and were forced to rely mostly on their internal funds.

The Russian financial crisis occurred in August, 1998, and mostly hit the countries heavily dependent on the export of raw materials. All the former USSR countries were affected by the crisis. First, the export and import firms suffered from the crisis due to decline in trade and exchange rate pressures. Second, the majority of firms were affected by an increase of interest rates and decrease of equity prices. However, the Russian crisis had no impact on the structural reforms in Eastern and Central Europe (Backe and Fidrmuc 2000).

On the whole, the transition process was particularly prompt in the EU-applicant countries $^{1}$ because, despite socio-political aspects, their economies had to satisfy the EU requirements or had well-functioning market economies with agents able to compete at the EU level. Definitely, the economic adjustments to the level appropriate for EU membership affected firms' behavior. After the accession of Central and Eastern European countries to the EU, firms obtained significant benefits. For example, barriers to trade and investment were eliminated and firms got access to the international (EU) market, and what is more important, to international credit markets.

\footnotetext{
${ }^{1}$ Bulgaria, the Czech Republic, Estonia, Hungary, Latvia, Lithuania, Poland, Romania, Slovakia, and Slovenia.
} 
Taking into account the considered events, I investigate whether the capital structure of firms in Eastern and Central European countries exhibits the same level of persistence as in the US or rather actively changes in response to economic evolution.

The paper is organized as follows. In the next section I survey the literature. In section 3 , I describe the traditional determinants of capital structure and their possible signs in transition economies. Section 4 describes the data sources and provides summary statistics of the sample. In section 5, I present the models and discuss the obtained results. I summarize the paper and conclude in section 6 .

\section{Literature}

The question about the choice of capital structure by firms is fundamental in the financial literature. This literature is fairly extensive and includes contributions by Titman and Wessels (1988), Rajan and Zingales (1995) and Frank and Goyal (2009). Scholars have identified a number of factors which are correlated with leverage. For example, Frank and Goyal (2009) begin with a long list of factors from prior literature. They choose six factors (industry median leverage, market-to-book assets ratio, tangibility, profitability, firm size and expected inflation) that account for more than $27 \%$ of the variation in leverage, while another 19 factors improve the explanatory power of the model by only $2 \%$. The set of leverage determinants identified by Frank and Goyal (2009) is employed by a large number of studies ${ }^{2}$.

However, a recent paper of Lemmon, Roberts, and Zender (2008) notes that traditional leverage determinants explain a minor part of the variation in leverage (at most 30\%), while $60 \%$ remain unexplained. This variation comes from an unobserved firm-specific time-invariant component that is responsible for persistence in leverage ratios over time. As the authors focus on the US economy, which is relatively stable, it is not clear whether leverage ratios exhibit a similar level of persistence when the economic environment rapidly changes over time. To answer

\footnotetext{
${ }^{2}$ The studies usually cite unpublished version of the Frank and Goyal paper.
} 
this question I will study transition economies.

There are only a few papers that attempt to study the capital structure of firms in transition economies. Some of them are concentrated on the firm-specific determinants. Cornelli, Portes, and Schaffer (1996) and Delcoure (2007) investigate capital structure determinants and find that leverage ratios of firms in transition economies behave differently from leverage ratios of firms in Western economies. For example, asset tangibility and profitability are negatively related to leverage in transition countries, while studies on Western firms report positive relationships. Cornelli, Portes, and Schaffer (1996) explain the negative relation between leverage and asset tangibility by the poor prospects of the previously capital-intensive sectors in the new environment and the negative relation between profitability and leverage by credit rationing.

Apart from static leverage regressions, scholars employ a dynamic capital structure model. They assume that firms have their target leverage level and the actual leverage of the firm deviates from the target level due to adjustment costs. The dynamic capital structure in transition economies is studied by Haas and Peeters (2006) and Nivorozhkin (2005). The authors apply methodology that allows both the target leverage and the adjustment speed to vary across firms and over time. They find that the determinants of target capital structure of firms in transition countries are similar to those observed in western countries. According to them, profitability and firm age appear to be the most robust determinants of target leverage ratios among transition countries.

Unlike previously considered studies, Joeveer (2006) investigates the significance of firm-specific, country institutional and also macroeconomic factors in explaining variation in leverage ratios. The study focuses on Eastern European countries ${ }^{3}$ from 1995 to 2002. Joeveer (2006) finds that firm-specific factors mostly explain the variation in leverage for listed and large unlisted firms, while country-specific factors are responsible for the variation in leverage of small unlisted firms.

\footnotetext{
${ }^{3}$ Bulgaria, the Czech Republic, Estonia, Hungary, Latvia, Lithuania, Poland, Romania and Slovakia.
} 
My paper differs from existing studies by focusing on the question of capital structure stability and its sources. I expect that the rigidity of capital structure is determined by the stability of the economy. Thus, the capital structure of firms in Eastern and Central Europe evolves in response to economic changes. Furthermore, I anticipate that stabilisation of leverage ratios occurs after EU enlargement in 2004 because the accession countries have achieved a certain level of economic and sociopolitical development required by the EU, major economic changes have completed, and economic stability has increased compared to the transition period.

In addition, I attempt to investigate whether the ownership structure is able to explain the part of unexplained firm-specific variation in leverage. My motivation for the inclusion of this factor into the model is based on the existing differences in ownership patterns between the US and Europe. In the US, dispersed ownership prevails, while in Europe it is more concentrated. Majority ownership not only gives a right to make important strategic decisions, but also creates strong incentives to monitor managers. The controlling share owner is directly interested in firm performance and is likely to take part in firm capital structure decisions. Thus, ownership structure seems to be an important determinant of firm capital structure.

\section{Leverage Factors}

Below I briefly describe the determinants of capital structure suggested by theory and by recent studies of capital structure in transition economies.

\section{Profitability}

On the one hand, financial structure theory considers debt as an instrument to reduce agency cost. Debt is used as a monitoring device that prevents managers from building their own empires (Jensen 1986). Moreover, debt could be served as a tax shield. So, the more profitable firms demand more debt and the relation between profitability and leverage is positive. On the other hand, when asymmetric information is great and, consequently, bank interest rates are high, large profitable 
firms will choose to use their internal sources, but others will have to borrow. This implies a negative relation between profitability and leverage.

Previous studies (Rajan and Zingales 1995, Joeveer 2006, and Haas and Peeters 2006) have identified statistically significant negative relationships between profitability and leverage. Profitability is calculated as operating profit (loss) before tax over total assets (Haas and Peeters 2006).

\section{Growth Opportunities}

According to the pecking order theory, firms that are expecting high growth in the future require additional equity financing. In order to use profitable investment opportunities, rapidly growing firms tend to be less leveraged. Furthermore, agency theory (Jensen 1986) argues that firms with greater opportunities for shareholders could choose investments and it leads to wealth expropriation from debt holders. Thus, a negative relation between growth opportunities is expected. At the same time, a fast-growing firm cannot fully rely on internal funds. A shortage of financial sources will be covered by issuing debt. ${ }^{4}$ This implies a positive relation between growth opportunities and leverage, which is consistent with existing literature.

I proxy growth opportunities by GDP growth.

\section{Size}

There are several reasons for a positive relation between size and leverage. First, size could be a proxy for the probability of default because larger firms tend be more diversified and, consequently, have lower risk of bankruptcy. Bankruptcy costs are also lower for large firms meaning a lower price of leverage. Second, the larger firms with diversified ownership structure are less able to control managers, but debt is a monitoring device. Third, a larger firm is associated with higher transparency even in transition economies where asymmetric information is large. Thus, it is easier for them to obtain bank credit. In addition, they are more likely to have access to international credit markets. For all these reasons large firms will demand more debt.

\footnotetext{
${ }^{4}$ Similar to Haas and Peeters (2006), the possibility of issuing equity is not considered.
} 
However, Titman and Wessels (1988) find a negative relationship between size and leverage, while Haas and Peeters (2006) and Joeveer (2006) report a positive relationship. The difference in obtained results could be determined by the fact that larger firms are able to issue more equity than small firms due to lower asymmetric information with financial markets. ${ }^{5}$ This is mostly the case of developed countries with low financial distress.

Size is proxied by the natural logarithm of total assets.

\section{Tangibility of Assets}

Theory suggests that tangible assets could be used as collateral. Collateral usage decreases agency costs of debt or reduces the lender's risk and protects them from the moral hazard problem caused by shareholders-lenders conflict of interests. In this situation a positive relationship is expected. However, when tangible assets are firm-specific, their liquidation value is low and firms in transition economies are forced to finance them internally, which would imply a negative relationship between leverage and a firm's tangible assets.

Evidence on the relationships between tangibility and leverage could be determined by economic development. Rajan and Zingales (1995), and Delcoure (2007) report that they are positive, but Haas and Peeters (2006), and Joeveer (2006) find them negative.

Tangibility of assets is measured as tangible fixed assets over total fixed assets.

\section{Maturity of Assets}

There is evidence that firms strive to match the maturity of assets and liabilities in order to reduce the risk of bankruptcy (Morris 1976, Hol and der Wijst 2008, Heyman, Deloof, and Ooghe 2008). If a maturity of debt is shorter than the maturity of assets, then return generated by assets might not be sufficient to repay the debt or enough cash might not be available. At the same time, if a maturity of debt is longer than the maturity of assets, the firms might have problems with finding new assets to support the debt.

\footnotetext{
${ }^{5}$ According to the pecking order hypothesis.
} 
Hol and der Wijst (2008) find a positive relation between assets maturity and short-term debt and a negative relation with long-term debt.

The maturity of assets is measured as current assets to total assets.

Corruption Perception Index (CPI)

CPI measures corruption defined by Transparency International as the misuse of entrusted power for private gain. In other words, the index measures an institutional quality and provides both time-series and cross-sectional variation.

I expect positive relation between firm's leverage and CPI, because lower CPI means lower institutional quality and higher asymmetric information. So, it is more difficult for an ordinary firm to obtain financing from banks. However, Fan, Titman, and Twite (2008) argue that CPI could reflect the possibility of investor rights being expropriated by managers or authorities. They find that the frequency of using debt by firms is higher than frequency of using equity in more corrupted countries because it is more difficult to expropriate debt holders than outside equity holders.

The index ranging from 0 to 10 with the lower values indicating more severe corruption.

Age

Age is found to be a significant determinant of capital structure in transition economies (Haas and Peeters 2006, Joeveer 2006). Older firms have lasting relationships with business and financial partners resulting in certain reputation, lower information asymmetries, and higher leverage. This implies a positive relationship between firm age and leverage.

Age is computed as the natural logarithm of the difference between the last observed year and year of incorporation.

\section{Industry Median Leverage}

Industries differ by their leverage level. These differences are determined by inter-industry heterogeneity in technology, assets, risk, etc. Firms operating in industries where median leverage is high tend to have high leverage. However, 
it could be that managers use the industry median as a benchmark for a firm's leverage. Frank and Goyal (2009) argue that industry median is robust to the leverage definition. A positive relationship between industry median and leverage is expected.

Median industry leverage is measured as median of leverage by NACE code and by year.

\section{Data}

The firm-level data is obtained from the Amadeus database constructed by Bureau Van Dijk. This database is the most comprehensive source containing financial information on public and private companies in Europe. The Amadeus database is available in different modules that are Top 250,000 companies, Top 1.5 million and all companies (around 1 million companies in 41 European countries). In this study I use the Top 1 million companies and focus on eight Eastern European countries (the Czech Republic, Estonia, Hungary, Latvia, Lithuania, Poland, Slovakia, Slovenia) between 1996 and $2006 .^{6}$

While the biggest problem of the data from transition economies is missing values, I require that all key variables have nonmissing data. I keep only firms that have leverage from zero to one interval. Firms from financial intermediation sector are excluded from the sample since they have a specific liability structure. Similar to Haas and Peeters (2006), I exclude observations if the sum of current and noncurrent liabilities does not exceed the trade credit because in this case, according to leverage definition, the numerator is negative. ${ }^{7}$ Observations where capital is negative are excluded as well. The construction of all of the variables used in the study is presented in the Appendix.

The resulting sample is unbalanced and the number of observations across countries varies. Estonia, Hungary and the Czech Republic have the greatest coverage,

\footnotetext{
${ }^{6}$ I would like to thank the Organizational Dynamics Graduate Studies Program, the University of Pennsylvania for access to this data.

${ }^{7}$ See Appendix.
} 
while Lithuania and the Slovak Republic have the lowest coverage. The mean leverage in all countries is in the $40 \%$ range, however, it is lower in Estonia (0.37) and about 50\% in the Czech Republic and Latvia. The largest firms in terms of total assets are located in Poland. In terms of profitability, firms' mean return in assets is larger than their median return. This implies that firms' profitability distribution is positively skewed and most firms have low profitability, while only a few firms have very high profitability. The average age of firms in the sample is about 7 years. Table 1 presents summary statistics for all of the firms in the sample.

\section{$5 \quad$ Model}

\subsection{The Determinants of Leverage in Transition Economies}

I start studying the determinants of leverage ratios using cross-sectional regressions as in Rajan and Zingales (1995), and in Frank and Goyal (2009).

$$
Y_{i j t}=\alpha+\beta X_{i j t-1}+\nu_{t}+\gamma_{j}+\epsilon_{i j t}
$$

where $Y_{i j t}$ is leverage of firm $i$ in country $j$ at time $t$; $\nu$ is a time fixed effect and $\epsilon$ is a random error term. Since residuals of given firm may be correlated across years (unobserved firm effect) and the sample contains more firms than years, an appropriate way will be to include dummy variables for each time period, each country and then cluster by firm. Using this approach requires year and firm effects to be unchanged over time. When year effect is fixed, time dummies will remove the correlation between observations in the same time period and only the firm effect will be in the data. The assumption of fixed firm effect is quite fair because I have a short panel where it is impossible to distinguish between permanent and temporary firm effects (Petersen 2009).

The results are presented in Table 2. To control for scale effects, I scale all variables by the total assets. In addition, explanatory variables are lagged one 
period to control for potential endogeneity issues. ${ }^{8}$

In the first column I focus on the core determinants ${ }^{9}$ of firms' leverage ratios identified by previous studies (Rajan and Zingales 1995, Frank and Goyal 2009). These six factors which are size, tangibility, profitability and growth opportunities, industry median and expected inflation account for only $8.04 \%$ of the variation in capital structure. The results I obtain are similar to previous works examining transition economies. Size of the firm and GDP growth have a positive and highly significant effect. Tangibility is positively related to leverage, but significant only at $10 \%$ level. However, it appears that profitability is insignificant, while industry median leverage and expected inflation have a strong positive effect on leverage.

In the second column I also add firm age, maturity of assets, CPI and a dummy for listed firms. Unexpectedly, age of the firm is negatively related to leverage ratio (contrary to Haas and Peeters (2006), but consistent with Brav (2009)). On the one hand, older firms are better known on the market. They have a certain reputation and lower information asymmetries, thus, it is easier for them to obtain credit. On the other hand, a negative sign could be due to older firms that are able to finance their operations from their internal sources and prefer to do so rather than use the external sources. The dummy for firm status is negatively related to leverage and highly significant, which is consistent with Brav (2009) who demonstrates that public firms in the UK have lower leverage than private firms. In this specification, tangibility is significant at the $10 \%$ level and positively related to leverage, which is consistent with studies from developed economies, while expected inflation loses its significance.

Finally, the last column examines only profitable firms. It could be seen that all the determinants except expected inflation and growth opportunities of the firm proxied by GDP growth are significant. Assets maturity has a negative impact

\footnotetext{
${ }^{8}$ Related studies of leverage determinants in transition economies (Delcoure 2007 and Joeveer 2006) do not account for potential endogeneity.

${ }^{9}$ Dividend payments and market-to-book ratio are not included because the overwhelming majority of firms in the sample $(387,176$ out of 388,896$)$ are unlisted and the data are not available for them.
} 
on leverage. As expected, CPI positively affects leverage of the firm meaning that lower corruption in the country leads to higher debt levels. This contradicts Fan, Titman, and Twite (2008) who find that higher corruption level is associated with higher debt usage.

In order to look at the differences in leverage between public and private firms, I conduct an analysis based on the firm's status (Table 3).

I find that all firm-specific factors are significant determinants of leverage despite tangibility, which is measured imprecisely for the subsample of listed firms. This is generally consistent with Joeveer (2006) (only profitability and age of the firm appear to be insignificant factors) and Delcoure (2007) (all factors have an important impact on leverage despite of firm's growth opportunities). In addition, external factors such as GDP growth and industry median leverage are highly statistically significant. As expected, there is a positive relation between leverage and industry median leverage, meaning that firms use industry median leverage as a benchmark and adjust their own leverage accordingly. A negative relation between leverage and GDP growth is consistent with Joeveer (2006) for broad leverage ${ }^{10}$ of public firms. However, corruption level appears to be an insignificant leverage determinant for listed firms because they are subject to strong regulation.

Similar to public firms, leverage of unlisted firms tends to be positively related to firm size and industry median leverage. Notice that for unlisted firms industry median leverage has greater impact than for listed firms (0.64 compared to 0.41$)$. Moreover, such firm-specific determinant as tangibility is significant at the $10 \%$ level and has positive coefficient. Profitability and expected inflation are measured imprecisely. In contrast to listed firms, CPI is significant and positively affects leverage of unlisted firms. This is consistent with the hypothesis that the lower index or higher corruption leads to higher asymmetric information, which restrains firms from obtaining external financing. Age of the firm and maturity of assets have a negative impact on the leverage of unlisted firms. Both factors are strongly

\footnotetext{
${ }^{10}$ The definition of broad leverage is in the Appendix.
} 
significant. Interesting, the maturity of assets is positively related to leverage of public firms, but negatively related to leverage of private firms. In line with the finding of Hol and der Wijst (2008), this could be considered as evidence of shortterm debt financing usage by public firms, while private firms mostly rely on longterm debt. On the whole, the findings for unlisted firms are in line with Joeveer (2006).

\subsection{How much of the Variation in Leverage is Firm-specific Time-invariant?}

Recent findings of Lemmon, Roberts, and Zender (2008) point out that traditional leverage determinants account only for a modest part of the variation in leverage, while firms' fixed effect regression explains about $60 \%$ of the variation. In order to investigate whether the fixed effect is responsible for the majority of the variation in leverage in transition economies, I run the following regression (Lemmon, Roberts, and Zender 2008).

$$
\begin{gathered}
Y_{i j t}=\alpha+\beta X_{i j t-1}+\eta_{i}+\nu_{t}+\gamma_{j}+u_{i j t}, \\
u_{i j t}=\rho u_{i j t-1}+w_{i j t}
\end{gathered}
$$

where $u$ is stationary, $w$ is a random disturbance that is assumed to be possibly heteroskedastic, but serially and cross-sectionally uncorrelated, $\eta$ is a firm fixed effect.

In order to answer the question how much of the variation is firm-specific and time-invariant, I run the regression of leverage on firm fixed effects. The adjusted $R^{2}$ from this regression is about $65 \%$, which is larger than in the US. Then I conduct a sensitivity analysis by considering only firms that have at least 5, 7, and 10 years of non-missing data for book assets. I find that the variation explained by firm fixed effects approaches $60 \%$ as the number of years available increases. However, it is quite surprising that even in rapidly changing transition economies, the fixed effect 
is responsible for the same or even larger part of the variation in leverage.

Furthermore, I estimate leverage regression by pooled OLS, fixed effect and random effect models for listed and unlisted firms. Table 4 contains the obtained results. As I reported above in the case of pooled OLS model, all factors except profitability and expected inflation have a significant impact on leverage of unlisted firms. In the case of public firms, tangibility and CPI are measured imprecisely. In line with Delcoure (2007) and Haas and Peeters (2006) studies of transition economies, Frank and Goyal (2009), and Lemmon, Roberts, and Zender (2008) of the US, the estimated relation between leverage level and tangibility is positive. However, the coefficient is significant only for unlisted firms. The pooled OLS model explains only about $9.6 \%$ of the variation in leverage of private firms and $22.6 \%$ of the variation in leverage of public firms. Fixed and random effect models perform better, while using Hausman specification test, the random effect model is rejected in favor of the fixed effect model. In case of unlisted firms all determinants are statistically significant despite tangibility and age of the firm, which are measured imprecisely. As expected, larger firms tend to have higher leverage because they are more diversified and face lower bankruptcy risk. Corruption index has a positive significant effect in the fixed effect model for both listed and unlisted firms.

Although the fixed effect model has a statistical advantage over the random effect and the pooled OLS models because it has the highest adjusted $R^{2}$, there is a certain threat that fixed effect estimation kills all of the cross-sectional variation and leave only the time-series variation in the data. However, it is acceptable when the cross-sectional and the time-series impacts are equal, but if this assumption is violated, fixed effect estimates are not able to capture the total impact of the leverage factors (Baranchuk and Xu 2009). 


\subsection{Ownership Structure of the Firm as a Determinant of Firm Capital Structure}

Besides analysing the stability of capital structure and the variation explained by previously identified determinants, I suggest looking at the ownership structure of the firm as a potentially important determinant of capital structure. European firms tend to be controlled by a major owner, the remainder is held by small investors. An owner of the firm is directly interested in firm's performance and trying to reduce risk of default through the financing choices. Higher debt levels are more likely to lead to default. The owner may choose to use a greater portion of equity in the capital structure. I distinguish between three ownership categories: majority ownership (>50\%); blocking minority ownership (>33\%, but $\leq 50 \%$ ); and legal minority ownership $(>10 \%$, but $\leq 33 \%){ }^{11}$

The majority ownership not only gives a right to make important strategic decisions, but also creates strong incentives to monitor managers because the controlling share owner is directly interested in the firm's performance. In addition, blocking minority ownership grants a right to block a number of decisions concerning major changes in the business activity of the firm. For example, blocking minority owners are able to block the decisions of the major shareholder concerning changes in assets and the firm's activities. Finally, legal minority ownership gives the possibility to delay or completely block the implementation of larger shareholders' decisions through lengthy court proceedings (Hanousek, Kocenda, and Svejnar 2007). Thus, ownership structure has the potential to be an important determinant of firm capital structure.

The concentration ownership dummies are defined in the following way (Bena and Hanousek 2008): majority ownership when firm is controlled by a majority owner and the rest are held by less than 10\%; monitored minority when despite

\footnotetext{
${ }^{11}$ The percentages for control rights are taken in accordance with Czech corporate law. The most difficult to decide about blocking minority ownership because it is usually defined differently in each corporate law. For example, for Hungary it is fixed at $25 \%$ of total stock and for the Czech Republic at $33 \%$. I also used the $20 \%$ threshold and obtained qualitatively the same results. So, I do not report them.
} 
the majority owner at least one minority owner is present; minority when either a blocking or legal minority owner is the largest owner; dispersed ownership is in case when all shareholders hold less than $10 \%$ of equity. I also distinguish between foreign and domestic owners. ${ }^{12}$

The direct ownership data are available starting from 2004. Descriptive statistics of the resulting subsample according to ownership concentration is in Table 5 . It can be seen from Table 5 that firms controlled by major owners are largest in terms of total assets. In fact, median total assets are significantly lower compared to their mean value. This fact suggests that total assets are positively skewed. In other words, total assets of most firms are low, while total assets of few firms are high. However, in terms of profitability, tangibility and leverage level, there are no significant differences with respect to ownership concentration.

Table 7 reports the results of leverage regression that accounts for ownership structure of the firm. The first column contains estimates from the pooled OLS regression I discussed above. In the second column I add ownership concentration variables to traditional leverage determinants. As can be seen from Table 7, it only slightly increases the explanatory power of the model. All the estimates stay approximately the same. At the same time, ownership concentration variables appear to be highly significant meaning that ownership structure of the firm affects its financial decisions. In the third column, in addition to ownership concentration, I also account for ownership domicile. Domestic ownership estimates for all concentration levels are significant and positively related to leverage. The obtained result is quite intuitive because obviously domestic owners are better informed about financing possibilities in their country, they most likely have informal contacts in banks and other credit institutions. However, only the foreign majority matters and does affect leverage level, while monitored majority and minority foreign owners estimates are insignificant.

\footnotetext{
${ }^{12}$ Table 6 presents summary statistics by domicile.
} 


\section{Conclusion}

Inspired by recent findings of Lemmon, Roberts, and Zender (2008) concerning capital structure stability in the US, I use a comprehensive database of firms in transition countries to study whether this significant stability in the leverage ratios is determined by the stability of the economic environment. First, I examined the explanatory power of leverage determinants identified by previous studies as relevant for both developed and transition economies. It appears that a number of core determinants are able to explain only about $8 \%$ of the variation in leverage. This percent is low mostly because the majority of firms in the sample is unlisted. For listed firms about $22 \%$ of the variation in leverage is explained by traditional determinants. However, listed companies are only about $1 \%$ of the entire sample. The obtained coefficient estimates are in line with estimates reported in earlier studies in transition economies (Joeveer 2006, Delcoure 2007). At the same time, the variation explained by traditional determinants in transition economies is lower than in developed economies.

Second, I focus on the question of capital structure stability. As I mention above, leverage ratios are stable over time in the US economy. Obviously, transition economies are different from the US economy. They have experienced overwhelming transformation and exogenous shocks. Although Eastern and Central European firms went through transition from central planning to market economy, privatization, the Russian financial crisis, and EU membership, the firm fixed effect is responsible for an even larger part of the variation in leverage meaning that capital structure of the firm has not even been affected by substantial economic transformations. It could be the case that credit constraints restrained firms from significant changes in capital structure. This is confirmed by studies of capital structure dynamics in transition countries, which report that firms in these economies tend to be underleveraged compared to their optimal leverage level and adjust their capital structures more slowly than firms in developed economies (Haas and Peeters 2006, Nivorozhkin 2005). So, in transition economies where asymmetric informa- 
tion is large, firms often may not be able to raise sufficient capital to finance viable projects. Financial institutions are eager to have full information about the firm that they are lending money to. However, the quality of the firm and quality of its investment projects is not always easy to verify. This process often takes time, thus, firms prefer to rely on their internal sources which implies certain rigidity in their leverage.

As the majority of the unexplained variation comes from unobserved timeinvariant firm characteristics, I look at ownership of the firm. The typical US/UK firm has a large number of shareholders, but no one investor owns a controlling share of the firm's stock. Thus, no one has control over a firm and can not directly monitor and replace the management. In contrast, European firms tend to be controlled by a major owner; the remainder is held by small investors. I control for majority ownership, monitored majority and minority. I find that direct ownership influences a firm decision concerning its capital structure. However, an ownership variable does not improve substantially the explanatory power of the model. The reason behind this could be that direct ownership is likely quite different from ultimate ownership. These differences in the ownership and control patterns might have important implications for the firm level decisions. In addition, capital structure decisions might be affected by the type of major owner. For example, firms owned by a bank may have higher leverage because financial organizations are more experienced in handling different kinds of risks. At the same time, industrial owners will more likely strive to minimize the risk of default, thus, they stick to the lower leverage level. Hence, further investigation of the role of ultimate ownership, type of major owner and credit constraints in the firm capital structure decisions is needed. 


\section{Appendix}

Leverage $=\frac{\text { debt }}{\text { debt+equity }}$, where debt=total liabilities-trade credit (Haas and Peeters 2006).

Broad leverage $=$ total liabilities $/$ total assets.

Narrow leverage $=\operatorname{debt(long-term}$ and short-term credit) $/($ debt + shareholders funds).

GDP growth is a proxy for growth opportunities of the firm.

Age $=\log \left(\right.$ Year $_{t}-$ year of incorporation $)$.

$\log ($ total assets) is the natural $\log$ of total assets.

Corruption Perception Index (CPI) is an index ranging from 0 to 10 . A lower value indicates more severe corruption.

Ownership dummies (Bena and Hanousek 2008):

Majority ownership $=1$, firm is controlled by a majority owner, the rest hold less than $10 \%$.

Monitored minority ownership $=1$, despite of the majority owner at least one minority owner is present.

Minority ownership=1, either blocking or legal minority owner is the largest owner. Dispersed ownership $=1$, all shareholders hold less than $10 \%$ of equity. 


\section{References}

Backe, P., and J. Fidrmuc. 2000. "The impact of Russian crisis on selected Central and Eastern European Countries." BOFIT, no. 9.

Baranchuk, N., and Y. Xu. 2009. "On the Persistence of Capital Structure Reinterpreting What We Know." Unpublished.

Bena, J., and J. Hanousek. 2008. "Rent Extraction by Large Shareholders: Evidence Using Dividend Policy in the Czech Republic." Finance a Uver: Czech Journal of Economics and Finance 58 (3): 106-130.

Brav, O. 2009. "Access to Capital, Capital Structure, and the Funding of the Firm." The Journal of Finance 64 (1): 263-308.

Cornelli, F., R. Portes, and M. E. Schaffer. 1996. "The Capital Structure of Firms in Central and Eastern Europe." CEPR Discussion Paper, vol. 1392.

Delcoure, N. 2007. "The determinants of capital structure in transitional economies." International Review of Economics and Finance 16:400-415.

Fan, J., S. Titman, and G. Twite. 2008. "An International Comparison of Capital Structure and Debt Maturity Choices." AFA 2005 Philadelphia Meetings.

Frank, M. Z., and V. K. Goyal. 2009. "Capital Structure Decisions: Which Factors are Reliably Important?" Financial Management 38 (1): 1-37.

Haas, R., and M. Peeters. 2006. "The dynamic adjustment towards target capital structure of firms in transition economies." Economics of Transition 14 (1): $133-169$.

Hanousek, J., E. Kocenda, and J. Svejnar. 2007. "Origin and Concentration: Corporate Ownership, Control and Performance in Firms After Privatization." Economics of Transition 15 (1): 1-31.

Heyman, D., M. Deloof, and H. Ooghe. 2008. "The Financial Structure of Private Held Belgian Firms." Small Business Economics 30:301-313. 
Hol, S., and N. Van der Wijst. 2008. "The Financial Structure of Nonlisted Firms." Applied Financial Economics 18:559-568.

Jensen, M. C. 1986. "Agency Costs of Free Cash Flow, Corporate Finance, and Takeovers." American Economic Review 76:323-329.

Joeveer, K. 2006. "Sources of capital structure: Evidence from transition countries." CERGE-EI Working Paper, no. 306.

Lemmon, M. L., M. R. Roberts, and J. F. Zender. 2008. "Back to the beginning: Persistence and the cross-section of corporate capital structure." Journal of Finance 63 (4): 1575-1608.

Morris, J. 1976. "On Corporate Debt Maturity Strategies." The Review of Financial Studies 31 (1): 29-37.

Nivorozhkin, E. 2005. "Financing Choices of Firms in EU Accession Countries." Emerging Markets Review 6:138-169.

Petersen, M. A. 2009. "Estimating Standard Errors in Finance Panel Data Sets: Comparing Approaches." The Review of Financial Studies 22 (1): 435-480.

Rajan, R. G., and L. Zingales. 1995. "What Do We Know About Capital Structure: Some Evidence from International Data." Journal of Finance 50:1421-1460.

Titman, S., and R. Wessels. 1988. "The determinants of capital structure choice." Journal of Finance 43:1-21. 
Table 1: Summary Statistics

The table reports summary statistics of the entire sample. Definitions of all variables are in the Appendix. Total assets are in thousands of USD.

\begin{tabular}{|c|c|c|c|c|c|c|}
\hline Country & 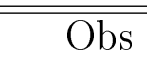 & Leverage & Total assets & $\overline{\mathrm{ROA}}$ & Tangibility & Age \\
\hline Czech Republic & 153410 & & & & & \\
\hline Mean & & 0.50 & 7057.1 & 0.09 & 0.34 & 7.5 \\
\hline Median & & 0.49 & 696.5 & 0.05 & 0.28 & 7 \\
\hline St. dev. & & 0.29 & 86870.9 & 2.72 & 0.38 & 4.6 \\
\hline Estonia & 203394 & & & & & \\
\hline Mean & & 0.37 & 686.9 & 0.09 & 0.39 & 6.0 \\
\hline Median & & 0.32 & 56.7 & 0.07 & 0.33 & 5 \\
\hline St. dev. & & 0.30 & 9417.3 & 0.59 & 0.30 & 6.1 \\
\hline Hungary & 486698 & & & & & \\
\hline Mean & & 0.48 & 1569.5 & 0.11 & 0.38 & 5.6 \\
\hline Median & & 0.48 & 62.4 & 0.05 & 0.29 & 5 \\
\hline St. dev. & & 0.29 & 101490.0 & 11.42 & 12.18 & 3.9 \\
\hline Lithuania & 23347 & & & & & \\
\hline Mean & & 0.44 & 3015.2 & 0.10 & 0.33 & 6.7 \\
\hline Median & & 0.41 & 651.0 & 0.07 & 0.28 & 7 \\
\hline St. dev. & & 0.27 & 22150.3 & 0.23 & 0.24 & 3.8 \\
\hline Latvia & 26150 & & & & & \\
\hline Mean & & 0.50 & 3550.4 & 0.11 & 0.35 & 6.6 \\
\hline Median & & 0.50 & 572.2 & 0.08 & 0.31 & 6 \\
\hline St. dev. & & 0.28 & 21710.6 & 0.20 & 0.25 & 3.6 \\
\hline Poland & 98328 & & & & & \\
\hline Mean & & 0.39 & 14495.5 & 0.09 & 0.38 & 17.5 \\
\hline Median & & 0.36 & 2467.5 & 0.07 & 0.33 & 10 \\
\hline St. dev. & & 0.26 & 107162.9 & 0.26 & 2.10 & 25.3 \\
\hline Slovak Republic & 23459 & & & & & \\
\hline Mean & & 0.43 & 10122.1 & 0.07 & 0.38 & 9.0 \\
\hline Median & & 0.40 & 1707.9 & 0.05 & 0.37 & 8 \\
\hline St. dev. & & 0.28 & 88404.4 & 0.28 & 0.27 & 8.3 \\
\hline
\end{tabular}


Table 2: Determinants of Leverage in Transition Economies: Pooled OLS The table reports parameter estimates from pooled panel OLS regression of book leverage and corrected for heteroskedasticity and correlation within firms standard errors (reported in parentheses) on different specifications. The dependent variable is Leverage. Independent variables are lagged one period. Definitions of all variables are in the Appendix. The regressions include twodigit NACE code dummies, year dummies and country dummies, which are not reported. *,**, and ${ }^{* * *}$ denote statistical significance at the $10 \%, 5 \%$, and $1 \%$ level correspondingly.

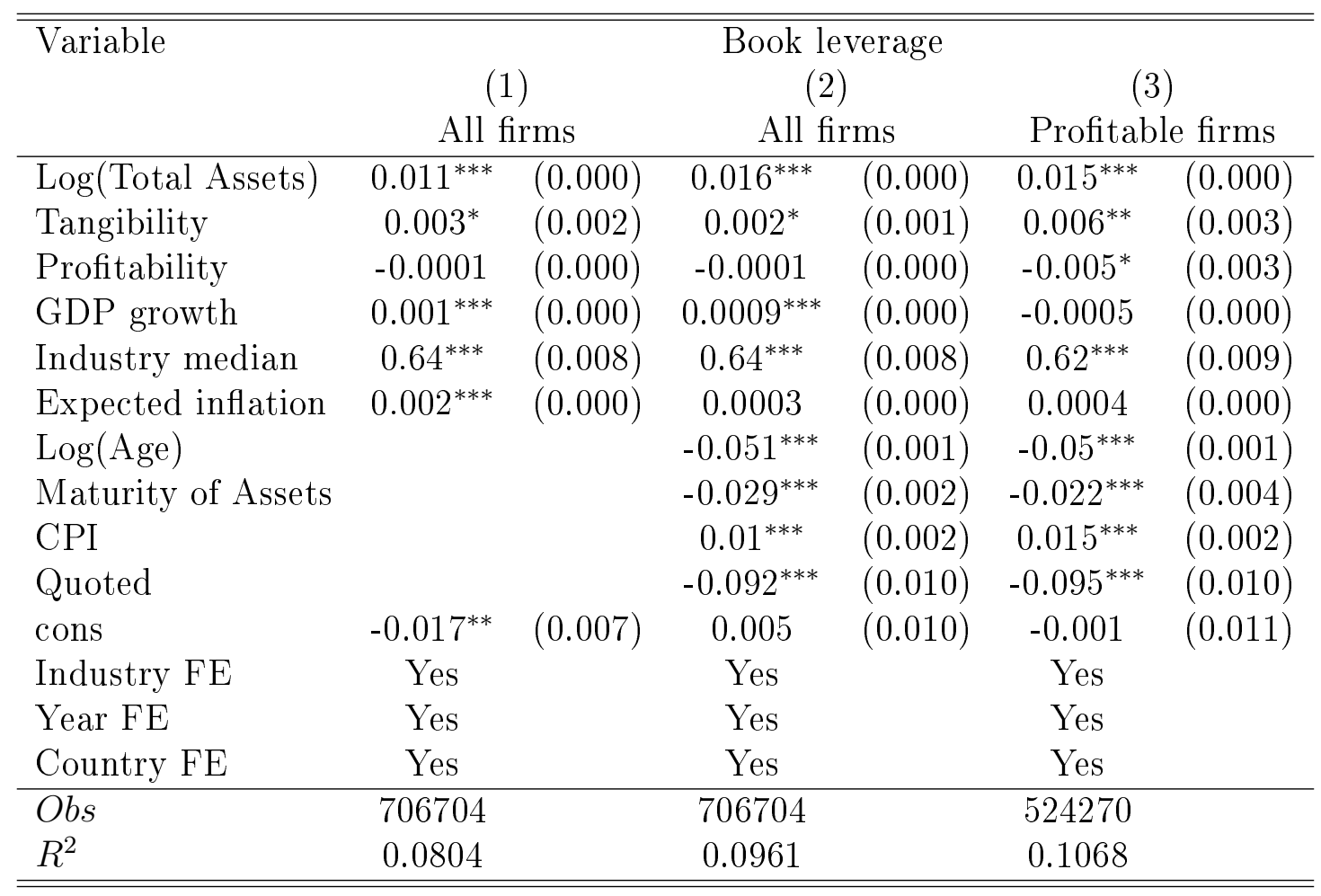


Table 3: Determinants of Leverage and the Status of the Firm: Pooled OLS The table reports parameter estimates from pooled panel OLS regression of book leverage with corrected for heteroskedasticity and correlation within firms standard errors (reported in parentheses). I distinguish between listed and unlisted firms. The dependent variable is Leverage. Independent variables are lagged one period. Definitions of all variables are in the Appendix. The regressions include two-digit NACE code dummies, year dummies and country dummies, which are not reported. $* * *$, and $* * *$ denote statistical significance at the $10 \%, 5 \%$, and $1 \%$ level correspondingly.

\begin{tabular}{|c|c|c|c|c|}
\hline \multirow[t]{2}{*}{ Variable } & \multicolumn{4}{|c|}{ Book leverage } \\
\hline & \multicolumn{2}{|c|}{ Listed firms } & \multicolumn{2}{|c|}{ Unlisted firms } \\
\hline Log(Total Assets) & $0.016^{* * *}$ & $(0.006)$ & $0.016^{* * *}$ & $(0.000)$ \\
\hline Tangibility & 0.045 & $(0.051)$ & $0.002^{*}$ & $(0.001)$ \\
\hline Profitability & $-0.003^{* *}$ & $(0.001)$ & -0.0001 & $(0.000)$ \\
\hline GDP growth & $-0.009^{* * *}$ & $(0.003)$ & $0.001^{* * *}$ & $(0.000)$ \\
\hline Industry median & $0.37^{* * *}$ & $(0.073)$ & $0.64^{* * *}$ & $(0.008)$ \\
\hline Expected inflation & $-0.004^{* *}$ & $(0.002)$ & 0.0003 & $(0.000)$ \\
\hline Log(Age) & $-0.026^{* *}$ & $(0.012)$ & $-0.051^{* * *}$ & $(0.001)$ \\
\hline Maturity of Assets & $0.15^{* *}$ & $(0.060)$ & $-0.030^{* * *}$ & $(0.002)$ \\
\hline $\mathrm{CPI}$ & 0.015 & $(0.015)$ & $0.01^{* * *}$ & $(0.002)$ \\
\hline cons & -0.19 & $(0.152)$ & 0.006 & $(0.010)$ \\
\hline Industry FE & Yes & & Yes & \\
\hline Year FE & Yes & & Yes & \\
\hline Country FE & Yes & & Yes & \\
\hline Obs & 2401 & & 704303 & \\
\hline$R^{2}$ & 0.2264 & & 0.0961 & \\
\hline
\end{tabular}


Table 4: Three Different Estimators of Leverage

The table reports parameter estimates from pooled OLS, fixed effect, and random effect regressions. The dependent variable is Leverage. Independent variables are lagged one period. Definitions of all variables are in the Appendix. The pooled OLS regression include year dummies, two-digit NACE code dummies, and country dummies, which are not reported. The pooled OLS standard errors are robust to heteroskedasticity and correlation within firm. Fixed effect standard errors are robust to heteroskedasticity and serial correlation within firms. $\operatorname{AR}(1)$ is the estimated first-order serial correlation coefficient. ${ }^{*}, * *$, and ${ }^{* * *}$ denote statistical significance at the $10 \%, 5 \%$, and $1 \%$ level correspondingly.

\begin{tabular}{lllllll}
\hline \hline & & & & \\
Book Leverage & \multicolumn{1}{c}{ Pooled OLS } & \multicolumn{1}{c}{ Fixed Effect } & Random Effect \\
\hline \multicolumn{7}{c}{ Panel A. Unlisted firms } \\
\hline Log(Total Assets) & $0.016^{* * *}$ & $(0.000)$ & $-0.014^{* * *}$ & $(0.001)$ & $0.012^{* * *}$ & $(0.000)$ \\
Tangibility & $0.002^{*}$ & $(0.001)$ & 0.00001 & $(0.000)$ & $0.0004^{* *}$ & $(0.000)$ \\
Profitability & -0.0001 & $(0.000)$ & $-0.00006^{* * *}$ & $(0.000)$ & -0.00002 & $(0.000)$ \\
GDP growth & $0.0008^{* * *}$ & $(0.000)$ & $-0.0009^{* * *}$ & $(0.000)$ & $-0.001^{* * *}$ & $(0.000)$ \\
Industry median & $0.64^{* * *}$ & $(0.008)$ & $0.30^{* * *}$ & $(0.008)$ & $0.57^{* * *}$ & $(0.004)$ \\
Expected inflation & 0.0004 & $(0.000)$ & $-0.001^{* * *}$ & $(0.000)$ & -0.0003 & $(0.000)$ \\
Log(Age) & $-0.051^{* * *}$ & $(0.001)$ & -0.002 & $(0.007)$ & $-0.047^{* * *}$ & $(0.001)$ \\
Maturity of Assets & $-0.030^{* * *}$ & $(0.002)$ & $-0.009^{* * *}$ & $(0.002)$ & $-0.034^{* * *}$ & $(0.001)$ \\
CPI & $0.0097^{* * *}$ & $(0.002)$ & $0.007^{* * *}$ & $(0.002)$ & $0.003^{* * *}$ & $(0.001)$ \\
cons & 0.005 & $(0.010)$ & $0.023^{* * *}$ & $(0.002)$ & $0.16^{* * *}$ & $(0.007)$ \\
\hline & & & & & & \\
Hausman test & & & 3897.15 & 0.0000 & & \\
Obs & 704303 & & 458259 & & 704587 & \\
AR(1) & & & 0.5151 & & 0.5151 & \\
$R^{2}$ & 0.0961 & & & & & \\
\hline
\end{tabular}

Panel B. Listed firms

\begin{tabular}{lllllll} 
Log(Total Assets) & $0.016^{* * *}$ & $(0.006)$ & 0.007 & $(0.011)$ & $0.011^{* *}$ & $(0.004)$ \\
Tangibility & 0.045 & $(0.051)$ & $0.11^{* *}$ & $(0.046)$ & 0.015 & $(0.031)$ \\
Profitability & $-0.003^{* *}$ & $(0.001)$ & -0.0015 & $(0.001)$ & -0.0016 & $(0.001)$ \\
GDP growth & $-0.009^{* * *}$ & $(0.003)$ & 0.001 & $(0.003)$ & $-0.008^{* * *}$ & $(0.002)$ \\
Industry median & $0.37^{* * *}$ & $(0.073)$ & 0.063 & $(0.053)$ & $0.21^{* * *}$ & $(0.043)$ \\
Expected inflation & $-0.004^{* *}$ & $(0.002)$ & -0.0007 & $(0.002)$ & $-0.005^{* * *}$ & $(0.002)$ \\
Log(Age) & $-0.026^{* *}$ & $(0.012)$ & -0.06 & $(0.065)$ & 0.007 & $(0.010)$ \\
Maturity of Assets & $0.15^{* *}$ & $(0.060)$ & 0.059 & $(0.038)$ & $0.071^{* *}$ & $(0.029)$ \\
CPI & 0.015 & $(0.015)$ & $0.050^{* * *}$ & $(0.018)$ & $0.021^{* *}$ & $(0.011)$ \\
cons & -0.19 & $(0.152)$ & 0.013 & $(0.030)$ & 0.021 & $(0.087)$ \\
\hline Hausman test & & & & & \\
Obs & 2401 & \multicolumn{7}{c}{63.91} & 0.0000 & & \\
AR(1) & 0.2264 & 0.5196 & & 2401 & \\
$R^{2}$ & \multicolumn{7}{c}{26} & & & \\
\hline \hline
\end{tabular}


Table 5: Summary Statistics by Concentration

\begin{tabular}{lrrrrr}
\hline \hline & & Mean & Median & Std & Obs \\
\hline Total assets (mil. USD) & Majority & 16.21 & 1.6 & 124.22 & 38,443 \\
& Monitored Majority & 6.87 & 0.82 & 139.85 & 13,681 \\
& Minority & 5.12 & 0.58 & 81.52 & 33,540 \\
Leverage & Dispersed & 6.58 & 0.65 & 86.86 & 9,333 \\
& Majority & 0.43 & 0.41 & 0.27 & 38,443 \\
& Monitored Majority & 0.46 & 0.45 & 0.26 & 13,681 \\
Profitability & Minority & 0.45 & 0.43 & 0.27 & 33,540 \\
& Dispersed & 0.43 & 0.42 & 0.26 & 9,333 \\
& Majority & 0.09 & 0.07 & 0.56 & 38,443 \\
Tangibility & Monitored Majority & 0.09 & 0.07 & 0.19 & 13,681 \\
& Minority & 0.1 & 0.07 & 0.24 & 33,540 \\
& Dispersed & 0.09 & 0.07 & 0.25 & 9,333 \\
& Majority & 0.35 & 0.3 & 0.27 & 38,443 \\
& Monitored Majority & 0.33 & 0.28 & 0.26 & 13,681 \\
& Minority & 0.33 & 0.28 & 0.3 & 33,540 \\
& Dispersed & 0.34 & 0.29 & 0.26 & 9,333 \\
\hline \hline
\end{tabular}

Table 6: Summary Statistics by Domicile

\begin{tabular}{rrrrrr}
\hline \hline & & Mean & Median & Std & Obs \\
\hline Total assets (mil. USD) & Domestic & 6.9 & 0.76 & 87.63 & 86,327 \\
& Foreign & 40.85 & 5.67 & 236.45 & 8,670 \\
Leverage & Domestic & 0.44 & 0.43 & 0.27 & 86,327 \\
& Foreign & 0.42 & 0.4 & 0.27 & 8,670 \\
Profitability & Domestic & 0.09 & 0.07 & 0.3 & 86,327 \\
& Foreign & 0.09 & 0.08 & 0.94 & 8,670 \\
Tangibility & Domestic & 0.34 & 0.29 & 0.28 & 86,327 \\
& Foreign & 0.31 & 0.26 & 0.26 & 8,670 \\
\hline \hline
\end{tabular}


Table 7: Leverage and Direct Ownership

The table reports parameter estimates from pooled panel OLS regression of book leverage with corrected for heteroskedasticity and correlation within firms standard errors (reported in parentheses). The dependent variable is Leverage. Independent variables are lagged one period. Definitions of all variables are in the Appendix. The regressions include year dummies, two-digit NACE code dummies, and country dummies, which are not reported. ${ }^{* * *}$, and $* * *$ denote statistical significance at the $10 \%, 5 \%$, and $1 \%$ level correspondingly.

\begin{tabular}{|c|c|c|c|c|c|c|}
\hline \multirow[t]{2}{*}{ Variable } & \multicolumn{6}{|c|}{ Book leverage } \\
\hline & \multicolumn{2}{|c|}{$(1)$} & \multicolumn{2}{|c|}{$(2)$} & \multicolumn{2}{|c|}{$(3)$} \\
\hline Log(Total Assets) & $0.007^{* * *}$ & $(0.001)$ & $0.007^{* * *}$ & $(0.001)$ & $0.007^{* * *}$ & $(0.001)$ \\
\hline Tangibility & $0.085^{* * *}$ & $(0.013)$ & $0.085^{* * *}$ & $(0.013)$ & $0.085^{* * *}$ & $(0.013)$ \\
\hline Profitability & -0.012 & $(0.009)$ & -0.012 & $(0.009)$ & -0.012 & $(0.009)$ \\
\hline GDP growth & $0.006^{* * *}$ & $(0.002)$ & $0.006^{* * *}$ & $(0.002)$ & $0.006^{* * *}$ & $(0.002)$ \\
\hline Industry median & $0.55^{* * *}$ & $(0.021)$ & $0.54^{* * *}$ & $(0.021)$ & $0.54^{* * *}$ & $(0.021)$ \\
\hline Expected inflation & $0.007^{* *}$ & $(0.003)$ & $0.007^{* *}$ & $(0.003)$ & $0.007^{* *}$ & $(0.003)$ \\
\hline Log(Age) & $-0.062^{* * *}$ & $(0.002)$ & $-0.062^{* * *}$ & $(0.002)$ & $-0.062^{* * *}$ & $(0.002)$ \\
\hline Maturity of Assets & $0.037^{* * *}$ & $(0.012)$ & $0.036^{* * *}$ & $(0.012)$ & $0.037^{* * *}$ & $(0.012)$ \\
\hline CPI & $-0.01^{*}$ & $(0.005)$ & $-0.010^{*}$ & $(0.005)$ & $-0.010^{*}$ & $(0.005)$ \\
\hline Quoted & 0.009 & $(0.014)$ & 0.014 & $(0.014)$ & 0.014 & $(0.014)$ \\
\hline Majority & & & $0.016^{* * *}$ & $(0.004)$ & & \\
\hline Monitored Majority & & & $0.020^{* * *}$ & $(0.004)$ & & \\
\hline Minority & & & $0.009^{* *}$ & $(0.004)$ & & \\
\hline Majority*foreign & & & & & $0.011^{*}$ & $(0.006)$ \\
\hline Majority*domestic & & & & & $0.018^{* * *}$ & $(0.004)$ \\
\hline Monitored Majority*foreign & & & & & -0.007 & $(0.012)$ \\
\hline Monitored Majority*domestic & & & & & $0.021^{* * *}$ & $(0.004)$ \\
\hline Minority*foreign & & & & & -0.001 & $(0.012)$ \\
\hline Minority*domestic & & & & & $0.01^{* *}$ & $(0.004)$ \\
\hline cons & $0.14^{* * *}$ & $(0.031)$ & $0.13^{* * *}$ & $(0.031)$ & $0.13^{* * *}$ & $(0.031)$ \\
\hline Industry FE & Yes & & Yes & & Yes & \\
\hline Year FE & Yes & & Yes & & Yes & \\
\hline Country FE & Yes & & Yes & & Yes & \\
\hline$N$ & 89464 & & 89464 & & 89464 & \\
\hline$R^{2}$ & 0.0963 & & 0.0968 & & 0.0968 & \\
\hline
\end{tabular}


Individual researchers, as well as the on-line and printed versions of the CERGE-EI Working Papers (including their dissemination) were supported from the European Structural Fund (within the Operational Programme Prague Adaptability), the budget of the City of Prague, the Czech Republic's state budget and the following institutional grants:

- Center of Advanced Political Economy Research [Centrum pro pokročilá politickoekonomická studia], No. LC542, (2005-2009),

- Economic Aspects of EU and EMU Entry [Ekonomické aspekty vstupu do Evropské unie a Evropské měnové unie], No. AVOZ70850503, (2005-2010);

- Economic Impact of European Integration on the Czech Republic [Ekonomické dopady evropské integrace na ČR], No. MSM0021620846, (2005-2011);

Specific research support and/or other grants the researchers/publications benefited from are acknowledged at the beginning of the Paper.

(c) Anastasiya Shamshur, 2009

All rights reserved. No part of this publication may be reproduced, stored in a retrieval system or transmitted in any form or by any means, electronic, mechanical or photocopying, recording, or otherwise without the prior permission of the publisher.

Published by

Charles University in Prague, Center for Economic Research and Graduate Education (CERGE) and

Economics Institute ASCR, v. v. i. (EI)

CERGE-El, Politických vězňů 7, 11121 Prague 1, tel.: +420 224005 153, Czech Republic.

Printed by CERGE-EI, Prague

Subscription: CERGE-EI homepage: http://www.cerge-ei.cz

Editors: Directors of CERGE and EI

Managing editors: Deputy Directors for Research of CERGE and EI

ISSN 1211-3298

ISBN 978-80-7343-195-2 (Univerzita Karlova. Centrum pro ekonomický výzkum

a doktorské studium)

ISBN 978-80-7344-184-5 (Národohospodářský ústav AV ČR, v. v. i.) 
CERGE-EI

P.O.BOX 882

Politických vězňů 7

11121 Praha 1

Czech Republic http://www.cerge-ei.cz 